\title{
Islamic Liquidity Management: The Way Forward
}

\author{
Muhammed İslami Önal*
}

\begin{abstract}
Even though very small compared with conventional finance, there has been significant growth in Islamic financial services during recent years. It is not surprising that this growth is forecast to continue at a rapid pace. Clearly, there is an expanding demand for these products, and a closely associated desire on the part of banks, including non-Islamic banks, to provide Islamic financial services. As the interest in the subject of Islamic finance increases, there appears the need for innovative and competitive Islamic products which are Sharia-compliant. On the other hand, the development of Islamic finance faces challenging issues. Liquidity management of Islamic financial institutions has been one of the most challenging and discussed issues with regard to the trend outlines above. Especially the short term-liquidity management issue is very problematic for these institutions since it is very hard to find globally accepted, Shariacompliant, liquid short term instruments that may be used in liquidity management. Recently, there have been attempts to provide these kind of instruments with no (little?) success being recorded as of date. The Islamic financial industry waits in eager anticipation for a solution to the problem that may present a way out of the current empasse.
\end{abstract}

Keywords: Islamic finance, islamic liquidity management, IILM

* Representative of the Central Bank of Turkey/Economic Counsellor of Turkey at Turkish Embassy in Kuala Lumpur, 118-Jalan U-Thant, 55000, Kuala Lumpur, Malaysia.

E-mail:muhammed.onal@tcmb.gov.tr 


\section{Introduction}

The Islamic financial system can be defined as a set of financial institutions and instruments (?) used by clients and institutions which provide opportunity for Sharia-compliant economic activities. Islamic Financial Institutions (IFIs) have become popular due to demand for specific financial services and as a result of the accumulation of substantial financial resources by certain Muslim countries. In the medium term, current trends of IFIs' development will be stable, considering that oil-exporting countries continue to receive substantial income and the financial markets of these countries are expected to continue to evolve.

On the other hand, during recent years traditional banks have displayed a great interest in entering the market of Islamic financial products. Thus the majority of multinational banks already have "Islamic windows". This is due to the increase of Muslim populations in developed countries as well as the growth of interest of Islamic investors in the geographic diversification of their investment portfolios. Additionally, as a consequence of global financial liberalization the extent of penetration of IFIs in the US and Western Europe appears to suggest that sooner or later they will potentially become a feature of all countries' financial systems. However, the full operation of IFIs will not be possible without the strengthening of liquidity management and changes in related legislation.

There have been many issues discussed with respect to Islamic finance and banking. In this sense liquidity management has been one of the most-discussed and challenging issues with respect to the above. The main reasons behind this issue coming to prominence are concerns regarding the degree to which liquidity is Sharia-compliant, the lack of properly structured and easily transferable instruments, the necessity for IFIs to maintain higher cash reserves when compared to their conventional counterpoints and their holding of a zero-return reserve in their portfolio which harms the profitability and competitiveness of the IFIs. Even though there exist successfully applied local products and instruments which have been customized by the monetary and regulatory authorities to help IFIs overcome this hardship and facilitate their liquidity management, there remains a clear lack of globally-recognized and widely-accepted instruments.

Islamic money markets need to be integrated globally, not only regarding relations between the IFIs themselves, but also with conventional markets in an efficient, Sharia-complaint and simple way to facilitate li- 
quidity management for IFIs and to ease the flow of funds between countries and different markets.

\section{Islamic Liquidity Management}

Liquidity management can simply be defined as the ability of a financial institution to remain 'liquid' enough to make its payments on time while maintaining an optimal cost-return balance to achieve that purpose by means of selecting and using the most appropriate tools for this aim. Meeting demand for deposit withdrawals and other cash outflows is a visible indicator of its viability. While goals and objectives can differ depending upon the circumstances and environment of the financial institution, a prudent liquidity management should always address ensuring enough liquidity to guarantee the orderly funding of the depositor's needs, providing a prudent cushion for unforeseen liquidity needs and investing liquid funds in a manner which emphasizes the need for security and liquidity. On the other hand, Islamic liquidity management does not differ from conventional liquidity management in terms of purpose and reasoning but with regard to the need to use different tools because of Sharia-compliance concerns. Islamic and conventional banking systems are similar as they are both based on fractional reserve systems and a depositor run on banking system constitutes the greatest risk and challenge to the liquidity management and financial system. But on the other hand development of a new Islamic financial instrument and a new structure to base the instrument on, as well as Sharia concerns, regulatory and tax treatments and leakages of funds in a dual-banking system expose additional risks in terms of developed Islamic liquidity management.

\section{Current Practices}

The Task Force on (for?) the Islamic Money Market, established by IFSB in 2008 and whose members consist of central bankers, bankers and regulators, released a technical note regarding the existing practices and infrastructure of the Islamic Money Markets and arrived at some recommendations for more efficient liquidity management. According to this report, in the countries which provided data, IFIs hold two to ten times more excess reserves at central banks as a percentage of their deposits compared to conventional ones so as to be able to remain sufficiently liquid. In other 
words, cash is the most used tool by its nature to remain liquid, but this comes at a cost to IFIs. This does not render cash as the optimal choice for IFIs, even though it constitutes the least risky choice, because it deprives the IFIs of a certain yield and flexibility provided by the tools which are used by their conventional peers.

The most common interbank tool which is used to facilitate fund transfer between a cash-surplus IFI and a deficit IFI with a specific amount of yield is the commodity- murabahah agreement. An underlying commodity is purchased by the cash-surplus bank and sold to the deficit bank on a deferred basis via an exchange platform such as the London Metal Exchange, Bursa Malaysia or with the assistance of some private companies which provide these kinds of platforms. This arrangement is widely used in all jurisdictions, but not in tradable transactions, even though this is standardised under Sharia Rules. Moreover there is a certain degree of market risk and this may not prove enough for monetary operations. Sukuk (Islamic bonds?) trading is another way of managing liquidity among the IFIs, but it is very rare due to underdeveloped secondary market trading, a tendency to 'buy and hold' and limited issuance of globally recognized tradable sukuk. There are other Islamic contracts such as wakalab to manage liquidity and facilitate funds transfer and, of course, spot FX markets are widely used to facilitate liquidity management.

Central Banks or Monetary Authorities of different jurisdictions develop and use different instruments to facilitate liquidity management for IFIs. As is well known, central banks have lending and borrowing facilities for the banks under their purview and can do outright sell and buy of a defined group of instruments for monetary policy purposes if it requires. In order for a bank to borrow from a central bank, it first needs to have a certain amount of collateral. For IFIs there need to exist Islamic securities. Central Bank of Malaysia has the first and only Islamic Interbank Market in the world which represents a real breakthrough in the attempts to facilitate Islamic liquidity management. There are several instruments used in this market which help Islamic financial institutions acquire sound liquidity management within the dual banking system of Malaysia. One of the most widely-used ones is Mudharabah Interbank Investment which refers to a mechanism whereby a deficit Islamic banking institution (i.e. an investee bank) can obtain investment from a surplus Islamic banking institution (investor bank) based on Mudharabah (profit sharing). The period of investment ranges from a period of overnight to 
12 months, while the rate of return is based on the rate of gross profit before distribution for investment of 1-year of the investee bank. Another instrument is wadiah acceptance which represents a transaction between the BNM and the Islamic banking institutions and refers to a mechanism whereby the Islamic banking institutions place their surplus funds with the BNM based on the concept of $A l$-Wadiah. Under this concept, the acceptor of funds is viewed as the custodian for the funds and there is no obligation on the part of the custodian to pay any return on the account. Moreover when the first Islamic bank in Malaysia began operations in 1983, the bank was unable, among other things, to purchase or trade in Malaysian Government Securities (MGS), Malaysian Treasury Bills (MTB) or other interest-bearing instruments. However, there was a serious need for the Islamic bank to hold such liquid papers to meet the statutory liquidity requirements as well as to place its 'idle fund'. To satisfy both requirements, the Malaysian Parliament passed the Government Investment Act in 1983 to enable the Government of Malaysia to issue non-interest bearing certificates known as Government Investment Certificates (GIC) which have now been replaced with Government Investment Issues (GII). One other important Islamic instrument on the Islamic interbank market are the Bank Negara Malaysia Ijarah Sukuk based on the Al-Ijarah or 'sale and lease back' concept, a structure that is widely used in the Middle East, too. A special-purpose vehicle, the BNM Sukuk Berhad as an SPV has been established to issue the sukuk Ijarah. The proceeds from the issuance are used to purchase Bank Negara Malaysia's assets. The assets are then leased to Bank Negara Malaysia for rental payment consideration, which is distributed to investors as a return on a semi-annual basis. Upon maturity of the sukuk, Ijarah SPV then sell the assets back to Bank Negara Malaysia at a predetermined price. On the other hand, the BNM has recently adopted the Collateralized Commodity Murabahah (CMM) which is also widely used and accepted as Shariah-compliant in GCC countries. This instrument can basically be seen as a form of commodity murabahah but CMM requires a borrowing party to present certain eligible collaterals to the lender as a rahn.

On the other hand, GCC Countries have established themselves as important players in the Islamic financial services industry. The GCC Central Banks issue Certificates of Deposits (CDs) for IFIs and this instrument is accepted as collateral by the central banks for Collateralized Commodity Murabahah (CMM) agreements which are used for the purpose 
of repo-like lending by the central bank concerned.. As a third alternative, and to cite another example other than Malaysia and the GCC states, in Turkey, the Treasury issues Revenue-Indexed Bonds (RIB) for IFIs and these are used as underlying securities in a SBBA agreement with the Central Bank of Turkey. However, due to concerns related to the degree of their Sharia compliance, RIBs have become a questionable investment tool and IFIs in Turkey. Last year in September 2012, the Turkish Treasury issued its first sovereign sukuk.

\section{Regulatory initiatives}

With respect to the regulatory environment, the Islamic Financial Services Board Task Force has stated important recommendations in order to provide for the establishment of a sound and efficient Islamic money market that could facilitate liquidity management by central banks and IFIs. According to these recommendations, the first important issue is to design Islamic money markets and Islamic government-financing instruments harbouring relatively low risk that are simply designed, regularly issued, widely held and accepted and supported by a robust payment and settlement system. The second issue is to incorporate Islamic governmentfinance instruments as an integral part of the overall public debt and financing programme, and foster the development of an Islamic government securities market. Thirdly, the active use of Islamic government finance instruments in market-based monetary operations of the central bank to manage the liquidity in the Islamic money market is another crucial issue. One other issue to be emphasized is the need to develop efficient trading arrangements and the associated market microstructure for Islamic money and government financial instruments, and develop foreign exchange markets in parallel. Lastly, the provision of supervisory guidance and incentives for effective liquidity risk and asset liability management by IFIs, and the fostering of privately issued Islamic money market securities hold great importance in successful liquidity management.

\section{The Way Forward}

Taking into consideration the recommendations proposed by the IFSB and the increasing need for short-term liquidity management in Islamic finance, several central banks, monetary authorities and multilateral 
organisations decided to create an international corporation to issue shortterm Sharia-compliant financial instruments to facilitate effective crossborder Islamic liquidity management. They named this organisation the International Islamic Liquidity Management Corporation (IILM) By creating more liquid Islamic financial markets for institutions offering Islamic financial services (IIFS), the main goal of the IILM has been established, that of enhancing cross-border investment flows, international linkages and financial stability.

Established in 2010 and headquartered in Kuala Lumpur, the shareholders of the IILM are the central banks or monetary authorities of Indonesia, Kuwait, Luxembourg, Malaysia, Mauritius, Nigeria, Qatar, Saudi Arabia, Turkey and the United Arab Emirates as well as the Islamic Development Bank. In 2012, Saudi Arabia vacated its membership and the share of Saudi Arabian Monetary Authority was divided between Qatar and Malaysia. As an international institution, IILM enjoys a range of privileges and immunities conferred by the Malaysian IILM Act of 2011. Membership of the IILM is open to central banks, monetary authorities, financial regulatory authorities or government ministries or agencies that have regulatory oversight of finance or trade and commerce, as well as to multilateral organisations.

So on the journey forward, with respect to Islamic liquidity management the IILM can play important roles. First of all, the IILM is expected to create globally recognized and highly rated short-term money market instruments in reserve currencies and regularly issued 3,6,12 month tenors with a relatively low risk. An internationally recognized settlement and custodian bank such as Euroclear or Clearstream is expected to be used to ensure a robust and credible settlement provision and to satisfy the warehousing purposes of future sukuk. Secondly, the IILM is supposed to acquire sovereign assets from member countries and finance-member countries. The IILM will consequently become a part of long-term government issuances and play an important role as a financing platform for local borrowing authorities. Hence, the IILM can help governments to issue Islamic securities or sukuk. Moreover, the sukuk of the ILLM might be accepted and used efficiently by central banks in their monetary policy applications. For example, central banks might accept the sukuk of the IILM as eligible collateral. In addition, to widen the market base and in order for central banks to have a quality asset alternative in their portfolio, IILM sukuk can be invested and traded in as well as employed for foreign- reserve manage- 
ment purposes. It can also be used as reverse repo instrument in tandem with local Islamic securities for the purpose of sterilisation of ample liquidity in both the Islamic and conventional banking systems. IILM sukuk can foster the flow of global Islamic funds as a perfect trade instrument. Considering that Islamic finance is based on trade, IILM sukuk can be traded on secondary markets efficiently through a strongly established chain of primary dealers. Since it is expected that there will be at least one primary dealer from each member jurisdiction within this chain than this will create liquidity and increase the tradability of the sukuk on the secondary market. Hence, through the establishment of a liquid secondary market over time, the IILM sukuk can help facilitate the short-term flow of funds and replace, in particular, costly and operationally burdening short-term cross-border commodity murabahah arrangements. Additionally, as a perfect liquid instrument it can attract conventional money market players, and facilitate the flow of funds between conventional and Islamic markets. Being issued in reserve currencies like USD, IILM sukuk can represent a good alternative as a foreign currency market instrument at the same time. Furthermore, IILM sukuk can serve to help lessen the negative effects of interconnectedness between Islamic and conventional markets as well as between different jurisdictions. Another important factor that should be cited is the way it can assist in creating an Islamic benchmark yield curve in the future and so become an important facilitator of Asset-Liability Management for IFIs considering its short-term, easily tradable, liquid nature. Since Islamic markets are still dependent upon conventional benchmarks in their pricing of Islamic instruments means that IILM sukuk may well prove successful in building a Islamic benchmark curve for the industry. This is currently a feature lacking in Islamic finance.

\section{Conclusion}

Islamic Liquidity Management has been one of the most challenging tasks for IFIs as different countries have been trying to facilitate the operations of their local Islamic banking sectors. Even IILM-style initiatives such as the Liquidity Management Center in Bahrain have been established by a consortium of private banks and the IDB has made an effort to set up a short-term sukuk program to facilitate liquidity management for IFIs. Unfortunately, these initiatives have not proved successful so far. IILM is the first initiative which is supported by central banks and 
monetary authorities. On the other hand, IILM faces some Shariah-related challenges especially in the sense of the need to find a generally accepted Islamic structure both for the underlying sovereign asset pool and future short-term sukuk. This is in addition to technical challenges such as the financing of high quality sovereign assets to obtain a high rating, the necessity to manage the duration mismatch between short-term liability and long term assets in a shariah-complaint way . IILM has to therefore find innovative ways in accordance with Shariah principles and obtain its members` support so as to overcome these technical difficulties and solve associated problems. Another factor that can contribute to IILM`s success will be a wide acceptance and extensive support of industry players. Fruitful cooperation, collaboration and synchronization between IILM, industry players, central banks and monetary and regulatory authorities will be the key determinant and catalyst in order to foster and facilitate not only domestic, but also cross-border Islamic liquidity management.

\section{REFERENCES}

Abdul-Rahman, Y. 1999. “Islamic Instruments for Managing Liquidity.” International Journal of Islamic Financial Services. 1(1). pp. 34-46.

Bhambra, H., 2007. "Supervisory implications of islamic finance in current regulatory environment". Islamic Finance: The Regulatory Challenge edited by Simon Archer and Rifaat Ahmed Abdul Karim, John Wiley and Sons, Singapore. 271-281.

Cox, S., 2007. "The Role of Capital Markets in Ensuring Islamic Financial Liquidity". Islamic Finance: The Regulatory Challenge edited by Simon Archer and Rifaat Ahmed Abdul Karim, John Wiley and Sons, Singapore. 271-281.

DFSA., "Islamic Banking and Liquidity Management." Available at: <http://www.dfsa. ae/Documents/Islamic\%20finance\%20docs\%20for\%20upload/Liquidity\%20 management.pdf> (Accessed 27 June 2013)

IFSB, Technical Note on Issues in Strengthening Liquidity Management of Institutions Offering Islamic Services: The Development of Islamic Money Markets, Available at: http://www.ifsb.org/docs/mar2008_liquidity.pdf

Salman, A., 2012. "State of Liquidity Management in Islamic Financial Institutions". IRTI Working Paper Series.

Vicary, D., 2010. "Liquidity Management in IFIs", 2nd Islamic Financial Stability Forum, Jeddah, Kingdom of Saudi Arabia,

Varren, E., 2003. "Islamic Liquidity Management", Islamic Banker Magazine

Weguelin, J., 2007. "Short Term Sukuk and Islamic Liquidity Management." EEIB. Available at: <http://www.meezanbank.com/docs/Short\%20Term\%20Sukuk\%20 and\%20Islamic\%20Liquidity\%20Management.pdf> (Accessed 11 June 2013). 


\title{
Turkey's Potential Role as a Global Leader in Islamic Banking and Finance
}

\author{
Humayon Dar*
}

Turkey possesses all the basic ingredients essential for becoming a global hub for Islamic banking and finance, which is known with a better term in the context of Turkey, i.e., participation banking. It has historical legacy of leadership of the Muslim world, has gone through a period of secularism, and has vibrant and growing economy that has a unique position of being part European and part Asian. By virtue of its geographical location, it enjoys the status of a bridge between Asia and Europe, and hence can serve as a bridge between the Islamic world and European continent. As other attempts in Europe to become a regional hub for Islamic banking and finance have seen only limited success, a window of opportunity has opened for Turkey to not only become a regional leader but also a global leader in Islamic banking and finance.

The biggest advantage that Turkey has over its competitors in Islamic banking and finance is in terms of the size of Muslim population and hence a potential domestic market. While Malaysia has emerged as a global leader in Islamic banking and finance, its growth potential is limited by its relatively small domestic market. Out of about 28 million people in Malaysia, only around $60 \%$ are Muslim. Another potential contender for global leadership in Islamic banking and finance, i.e., Saudi Arabia, has similar demographic credentials, with about 19 million Saudi nationals out of around 28 million people who live in the country. Again, domestic market size is rather limited. Other Gulf states also do not enjoy the benefits of large domestic markets, and hence can only serve as "off-shore" centres for Islamic banking and finance.

Other two countries that have potential to lead the global Islamic financial services industry are Pakistan and Indonesia, with huge domestic markets of about 190 million and 237 million people, respectively. With their populations being predominantly Muslim, Pakistan and Indonesia

* Chairman Edbiz Corporation, London, UK; Email: hdar@edbizconsulting.com 
can assume global leadership in Islamic banking and finance, if other aspects of their economies are developed strategically. Indonesia is a declared secular country like Turkey, while Pakistan is an Islamic state, with the religion of Islam enshrined in its constitution. In both the countries, however, there is growing recognition of importance of Islamic banking and finance and its relevance to economic growth and development.

In the backdrop of all this, Turkey is on track to becoming the next hub for Islamic banking and finance. Turkey can very easily assume a leadership role in the global Islamic financial services industry by forming and leading a group of I-5, the top 5 countries with the potential of leading the global Islamic financial services industries. These countries may include: Saudi Arabia, Malaysia, Pakistan, Indonesia and Turkey. These countries are not necessarily the top ranked countries in the Islamic Finance Country Index (IFCI), developed and published annually by the London-based Edbiz Consulting. Nevertheless, they can be knitted together strategically to form a block that may be used for developing Islamic banking and finance as a tool for integration of financial sectors in these countries. Table below lists top 10 countries ranked by IFCI.
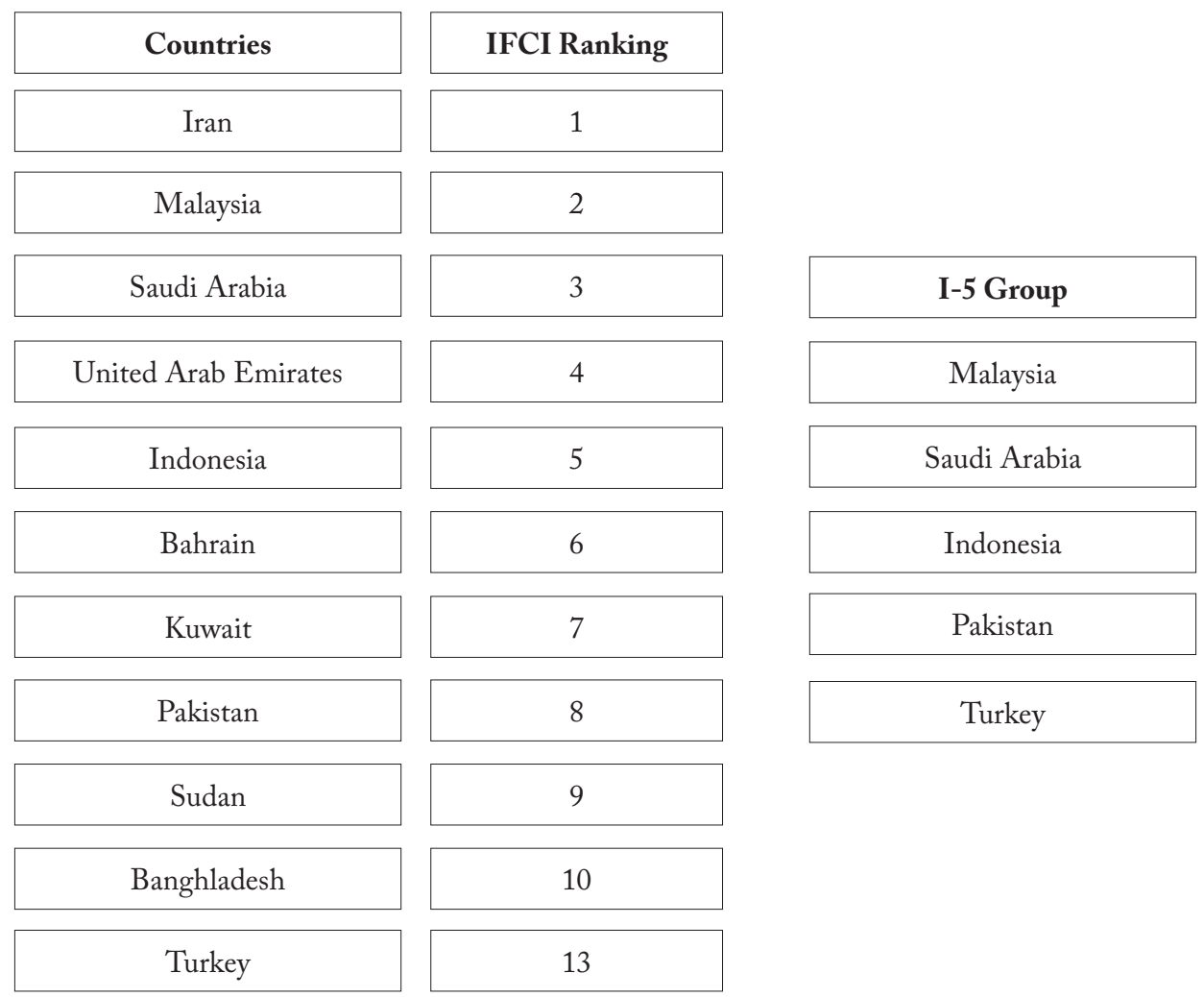
The successful dollar-denominated $\$ 1.5$ billion sovereign Sukuk issue, followed by a lira-denominated $\$ 900$ million sovereign Sukuk in 2012 put Turkey on the global platform of Islamic banking and finance. This has generated a lot of vibes in Islamic banking and finance internationally, and it is expected that many Middle Eastern Islamic banks and financial institutions will enter the Turkish market in the future. Turkey has always been a country of interest in Islamic banking and finance. Kuwait Finance House (KFH) entered Turkey in 1989, even without an explicit commitment from the then Turkish government to provide a level playing field to Islamic banking. It is interesting to note that KFH's entry into Turkey long preceded its move into other markets like Malaysia, Bahrain and Jordan.

Despite personal encouragement by the then governor of State Bank of Pakistan (SBP), Dr Ishrat Husain, KFH did not enter the Pakistan market and remains reluctant. On the other hand, Albaraka Bank has been operating in Turkey since 1984, well before it entered the Pakistani market in 1991. This preference tells a story, which policymakers in Turkey must read before delineating a comprehensive framework for developing the country into a global player and eventually an international centre of excellence in Islamic banking and finance.

In the absence of a platform like I-5, the major contenders for the role of global leadership may enter into an unhealthy competition to attract Islamic capital. Admittedly, only a fraction of US\$ 1.63 trillion under management of Islamic financial institutions is mobile in terms of crossborder flows. Independent national approaches to Islamic banking, without an effective international coordination, are sub-optimal. Without a wellthought-of global strategy, it will not be surprising if Pakistan or Malaysia start feeling threatened by Turkey that is better suited in terms of becoming a destination of preference for many Middle Eastern investors who currently invest in Pakistan and Malaysia. This is particularly important as for many institutions in the Middle East it makes more logistic sense to do business in Turkey rather than travelling to the Far East.

The proposed member states of I-5 possess unique value propositions. Pakistan, for example, presents arguably the most conservative model of Islamic banking in the world, based predominantly on Hanafi school of Islamic jurisprudence, which takes a rather conservative view in matters related to business and finance. There is a definite value proposition that Pakistan may offer to other members of the proposed I-5. Indonesian economy, being one of the fastest emerging markets in the world, must of- 
fer an array of economic opportunities to the Islamic financial institutions seeking Islamic financial assets. Malaysia is now in a position to share its expertise and experience in developing the most comprehensive regulatory framework for Islamic banking and finance. It is proposed that Malaysia should play a lead role to develop a comprehensive framework for an IBF (Islamic Banking and Finance) Passport for the Islamic financial institutions to operate freely in the member states of the proposed I-5. Saudi Arabia is in need of liberalisation of economy and the proposed I-5 offers it an opportunity to adopt an Islamic approach to liberalisation of financial sector. Turkey's leadership role in the I-5 can be maintained if the secretariat of the proposed group is located in Istanbul.

It is important for all the five countries to show more commitment to Islamic banking and finance and use it as a strategic tool to attract funding for a number of infrastructural projects (e.g., Jakarta Metro, electricity projects in Pakistan, etc.) that need external financing. Through adopting a combined leadership role in Islamic banking and finance, the proposed I-5 can serve as a financial powerhouse in the Organisation of Islamic Cooperation (OIC) block. Previously, a number of the OIC-level projects came to Pakistan, e.g., International Islamic Chamber of Commerce and Industry, which either failed or moved to other countries because of lack of support and commitment from the Pakistan government. Hence, it is important that the such new projects are initiated on the I-5 level so that right kind of support could be solicited from the member states, in case a host country faces some problems in implementing and operating such projects.

Given the growing interest in Islamic banking and finance in Turkey, it is perhaps a good opportunity for Pakistan, Indonesia, Malaysia and Saudi Arabia to bring the government of Turkey on board to form the proposed alliance. The more experienced members of the group can share their expertise in the field of Islamic banking and finance with those who lack such experiences and expertise. While the likes of Malaysia have invested millions of dollars to set up institutions like INCEIF to develop required human resources for Islamic banking, Pakistan can develop a state-of-theart centre of excellence for Islamic finance by investing a small amount in Darul Uloom Karachi, developing it into a teaching and research university specialising in Islamic banking and finance. If Turkey and Saudi Arabia can also play a role in this project, it would be a fantastic way of starting an everlasting collaboration in Islamic banking and finance amongst the countries involved. 
The Darul Uloom model of education is certainly more cost effective as compared with INCEIF, which has a huge annual budget. Close cooperation between Pakistan, Malaysia and Turkey can prove to be an efficient way of producing talent for the global Islamic financial services industry if right channels are created and maintained amongst respective parties. In fact, INCEIF could be developed an I-5 level project, which could be more cost effective and efficient than the existing structure of INCEIF.

Education is only one area for cooperation. The real benefits will accrue if the IBF Passport is developed for unrestricted operations for Islamic financial institutions across the I-5 block. 
